\title{
Relationship Between the Concepts of the Artistic Worlds Picture and the Discourse of the Georgian Poetry Written in the Russian Language
}

\author{
Tatiana Megrelishvili* \\ Georgian Technical University \\ 77 Kostava, Tbilisi, 0175, Georgia
}

Received 17.02.2015, received in revised form 19.05.2015, accepted 04.06.2015

The article examines the specific cultural discourse in the Russian poetry - the phenomenon of the contemporary cultural repertoire of Georgia. The analysis is carried out on the material of the study of the two dominant conceptosphere-concepts of "Russia" and "Tbilisi".

Keywords: Georgia's Russian-language poetry, post-Soviet space.

DOI: 10.17516/1997-1370-2015-8-7-1501-1510

Research area: philology.

\section{Introduction to the Problem of Research}

Dissolution of the Soviet Union led to the changes not only on the world political map, but also caused the changes of features of the cultural space that was formed during the Petersburg Empire. At the turn of the last two centuries on the ruins of this space complicated and ambiguous processes began, they were connected among the rest with creative work on the Russian language, so naturally it aroused a keen interest in the scientific circles. Creative work in the Russian language of this period is divided so to speak into three streams: on the one hand, literary creativity in the Russian language by authors who are immigrants from the former USSR, that live in different regions of the Western Europe and North America; on the other hand, one can observe this notion on the territory of those states of the postsoviet space where due to different historical reasons a large number of Russian-speaking people constantly lived (and live), and developed bilingualism with a language pair "national language - Russian language" is an indicator of the linguistic situation. Those two streams both form contemporary Russian-language literature ${ }^{1}$. Besides, Russian literature itself is developing in Russia.

One of the components of these global processes was a surge of literary activity of the Russian-speaking diaspora, which is a specific notion of the cultural repertoire of

(C) Siberian Federal University. All rights reserved

* Corresponding author E-mail address: tatamegre@gmail.com 
contemporary Georgia, where a cultural notion is recorded. The cultural notion should be called a contemporary Tbilisi literature in the Russian language, because Tbilisi has become a center of its localization (Megrelishvili, 2010; Megrelishvili 2012), though the process of creativity in Russian language is not something fundamentally new for the cultural repertoire of Georgia.

The history of literature in the Russian language in Georgia goes back to the $19^{\text {th }}$ century and includes different periods of stages of establishment and development.

At its origins the names of the classics of Georgian literature are highlighted in their artistic legacy one may find not only touches of the Russian language (Modebadze, 2007: 508516), but also sketches, essays and even poems written in Russian. By the early $20^{\text {th }}$ century, the social and cultural situation changed, and due to the extra literary factors during the period 19191921 Tbilisi $^{2}$ becomes a center of establishment of the literature in the Russian language of Georgia (Megrelishvili, 2008; Megrelishvili 2012). Representatives of multi-ethnic population of the city start to be the authors of "a creative product" in Russian language. At the beginning of the last century more than 70 print publications were published in Russian language in Tbilisi, several literary societies worked, including " $41^{0 "} " « 41^{0} »$ (K. Zdanevich, A. Kruchenih and etc.), such poets as I. Terentiev, S. Rafalovich, A. Chachikov (Chachikashvili), and a prose writer A. Antonovskaya and etc. created their works (Megrelishvili, Modebadze 2008; Megrelishvili 2008). These cultural figures had different life stories, but it is with their names the start of the full-scale development process of original Tbilisi Russian-speaking poets and prose writers creative work is connected. In the soviet period the authors that were writing in the Russian language were united by a Russian- speaking subdivision of the Union of Writers' of Georgia.

As we see during $19^{\text {th }}-20^{\text {th }}$ centuries the cultural repertoire of Georgia is characterized by, a presence of texts in Russian language in the corpus of classic Georgian literature, and by appearance of the Russian-speaking authors themselves. This process was highly developing during $20^{\text {th }}$ century. That is why the situation that was formed after 1990 does not seem to be strange.

In the fall of 1991 in Tbilisi, in the midst of turbulent political processes in the city center, in the former Noble Assembly began to gather young people involved in literary practice in Russian. Soon the efforts of Professor of Tbilisi University poet K.S. Gerasimov formed a youth poetic studio "Inhabited Island". At the same time in the building of the museum S.A. SmirnovaRosset the same professor Gerasimov created a union of writers named "Arion" (Megrelishvili 2012). With these two groups began the modern Russian-language literature of Georgia.

The studio "Inhabited Island" was perceived by all participants through a romantic prism of the old analogue - "a workshop of poets" of N. Gumilev, and the atmosphere of the revolutionary Tbilisi contributed to the formation of a direct analogy with the context of the Silver Age in the minds of all participants in the studio. A heady sense of freedom added new emotions: a freedom of creative experimentation, creative endeavors and bold judgments.

All members of both associations sharply criticized the socialist realism due to the illusion of "final truth", hypersociality, lack of freedom of the language plane, and in opposition to all this proclaimed an exciting game with hyperphenomena formed in their minds on the basis of modernism, which was a hobby for everyone at that time (Georgian, Russian, French modernism), the new colorful elements of 
revolutionary reality, in the course of the "game" exposed simulacra of the totalitarian ideology, its semantic void. The studio immediately stood out bright young talents, and for some time its image became associated with the names of young poets E. Kvirkeliia, D. Gagua, K. Kiknadze N. Gvelesiani, S. Armenian, who were students of a philological department of TSU named after Javakhishvili. However, due to a number of extra-literature reasons some time later "Inhabited Island" ceased to exist: the majority of its members in the period 1993-1995 for economic reasons left Georgia, and now they are citizens of Israel, the US and Russia. Only a few people, in particular N. Gvelesiani and S. Armenian remained in Georgia. Today, they are part of the Russian-speaking literary Tbilisi. However, "Arion" has grown and other organizations appeared (Megrelishvili 2011, Megrelishvili 2011).

The language of the literary works of modern Russian-speaking diaspora Georgia is Russian. At the same time, the authors of Russian-speaking literature of Georgia are not identical to ethnical identity. Among them, the percentage of ethnic Russian is relatively small: most of them are ethnic Georgians, Armenians, or the descendants of mixed marriages. Many of them received Russian-language education in the past, but it is not a permanent indicator. As a rule, all members of this community regardless of their ethnicity speak the Georgian language in everyday life. Among the authors, there are those who received education in the Georgian language, and write in two languages - Russian and Georgian, using both languages in their work (Nika Gomelauri, Guguli Keburia, et al.). They all share the language of creativity and life in the space of culture of Georgia. The literary process in Russian in Georgia is developing in many multifaceted genres, but the greatest number of pieces is the body of poetry.

\section{Theoretical} and Methodological Grounds

It is difficult to give a definite answer, whether the modern Russian-language literature in Georgia is a part of proper Russian literature or not, first of all, because of the phenomenon itself, which was formed, developed and had no time to settle and harden for scientific definitions; secondly, because such a determination may be the result of a lot of research, and not vice versa. And most importantly, watching it should be stated that the description and study of this phenomenon in all its complexity and the diversity of artistic processes requires interdisciplinary approaches that shed light on questions requiring its description and comprehension.

The relevant works considered problems and issues arising in the description and understanding of the Russian-language literature of Georgia:

- What is the dialectics of this phenomenon in the cultural reality of Georgia at the turn of the millennium?

- What are the common laws of this phenomenon in hindsight?

- What cultural paradigm can the Russianlanguage literature of Georgia be attributed to?

- How can the models of self-identification and self-reflection in the poetry of the Russian-speaking literary Tbilisi be described?

To date, a methodology and basic parameters of the study of literary processes in Russian are generally defined. They are based on a comparison of these processes with the leading trends of modern Russian literature. However, there is a reason to believe that in the case of modern Russian literature of Georgia we are faced with a particular model of development, which is different from other similar models ${ }^{3}$ emerging in the cultural space, called the Russian world. 


\section{Russian literature as a component of Tbilisi cultural discourse}

Today, in the cultural discourse of Tbilisi there is an interesting situation: the literary work in Russian there; along with experienced authors, quite often there are new names - the literary process is moving and is becoming of a more multi-genre character. However, the sociocultural conditions impose a special mark, giving the whole phenomenon peculiar coloring.

The readership of the authors, who write in Russian, is virtually nonexistent. This factor seems part of a wider phenomenon of today's reality - a decrease of interest in literature in the ranking of priorities of modern man. In addition, an important role in this process is the general situation in the book market of Georgia, where only commercial publishers operate today. Two Russian-language periodicals are being published: a literary almanac "On the hills of Georgia" (Ch. M. Aidinov - editor) and a glamorous magazine "Russian Club" (Ch. A. Svatikov - editor). There are online versions of a literary magazine "ABG" (ed. A. Shakhnazarov, M. Lyashenko). However, these publications do not reflect all aspects of the literary process, and works published on their pages, in their own literary quality is mixed. Almost all the collections of literary works of Russian writers of Georgia are issued in small batches on the money of the authors and the authors give printed copies away to their friends no commercial implementation.

There are several literary associations; the largest of them is "Arion", now headed by M.U. Aiudinova, and "MolotOk"(OK)", created in 2005 and led by A. Shakhnazarov and M. Liashenko. The form of the meetings in "Arion" resemble literary salons. The members of this union are striking figures of contemporary Russian-speaking literary Tbilisi: N. Selezneva, E. Dzhaparidze, I. Keskiull, R. Finn, M. Lamar E. Cherniaeva and others. "MolotOk" (youth association of writers living in Tbilisi $\mathrm{O}^{\prime} \mathrm{K}$ ) occupies a niche that was released after the termination of operation of the studio "Inhabited Island". Members of the association "MolotOk" $\left(\mathrm{O}^{\prime} \mathrm{K}\right)$ " are clearly inclined to the "left" experiments in poetry.

There is an association of writers and cultural workers "Novi Sovremennik" (The New Contemporary), headed by V. Sarishvili, where L. Oragvelidze, I. Paroshina, A. Grigorents and others work. In addition to these organizations, there are authors who do not belong to any union, but that their work is very noticeable. This is, first and foremost, I. Kulishova, D. Moniava, N. Gvelesiani.

Anyway, the millennium had a clear line in the field of literary discourse in Russian literature of Georgia: today it can be argued that the literary paradigm of the last century has given way to another, which is evolving before our eyes. This literary paradigm is formed as a reflection of the new worldview, a different view of the world, which is increasingly manifested in the personality of the creator. In addition, if you try to determine the type of literary vision of modern Russian-speaking literary creativity of Georgia in the 2010-ies, one should recognize the central methodological unit on the interpretation of the cultural discourse as a semiotic process, realized in various types of discourse practice.

One of the characteristic features of modern Russian-language poetry of Georgia is the creation of texts of metaphysical reality, which refers to nothing stood out for the signs of the real world but to other signs, which are regarded as a cumulative reality of Christian culture (Megrelishvili 2011, 569). Another feature of the new literary paradigm of Russian-language poetry Tbilisi was the refusal of faith in metanarratives, making the total simulation of life in favor of independence and freedom of personal fulfillment. Society of the recent past was obsessed with community, 
the primacy of the collective over the individual. Individualism was condemned as a grave sin. Public was put above personal. The texts of the authors of the Russian-language poetry of Tbilisi reveal a tendency to rehabilitate the rights of the individual to individual life (Megrelishvili 2011, 132).

\section{Concepts Russia and Tbilisi in the Literary World Picture of Modern Russian Authors of Georgia}

The most productive method for the analysis of relationships of concepts within the literary picture of the world and discourse allowed to clarify the question of the nature of the cultural identity of the creative product of modern Russianlanguage literature of Georgia, which in turn allowed to identify and describe patterns of selfidentification and self-reflection in contemporary Russian literature of Georgia (Megrelishvili 2012). One of the central cultural concepts ${ }^{4}$ of Tbilisi of Russian-language of modern poetry is the concept Russia. This concept is undergoing a complex transformation in the individual creative mind. The common field for all is the perception of this concept in the light of the new crosscultural discursive practices.

Liana Korchevskaya started writing back in the late 1990s, although the age belongs to the generation of whose youth came in 1950, a representative of the group of Russianspeaking literary Tbilisi, for whom the verse was compensated existential trauma, especially stung by our older generation. Before us is the representative of the so-called "naive poetry", which is at least a lower layer of metatext of Russian-language poetry of Georgia. In the poem "Rossiiushka" ("On the hills of Georgia" 2009, 23) felt an acute nostalgia, a longing for the lost Russia ("All is covered with snow, / cannot find a way to you"). The loss is associated with the new realities, compounded by difficulties finding the lost potential ("Dipped in blood nighttime / they are in my path"). The entire tone of the texts indicates that the author loves Russia, moreover, the author explicitly calls himself a "lost daughter" of Russia.

But in the world view of Irena Kesskiul (Irina Bagdoniene), a representative of the younger generation of Russian writers Georgia, whose work began in the early 1990s, the concept of Russia is filled with radically different than Korchevskya's, content and the author exposes the affinity of semiotic signs of classical Russian culture of the $19^{\text {th }}$ - beginning of the $20^{\text {th }}$ century. The poem about Russia "My Petersburg" (2009 Keskiul, 42) is written on behalf of the lyrical male person, rather than on behalf of a female person that is not typical for I. Keskiul'. The identity of the character is encoded in the text. $\mathrm{He}$ is from St. Petersburg ("My Bethlehem"), in fact - a person, as if symbolically inscribed in St. Petersburg text of Russian culture, part of the St. Petersburg myth. Given the bipolarity displayed components of the St. Petersburg myth, on which the poem is built, we can assume that this can be the lyrical character of Dostoevsky ("Slums fetid bowels; hail crippled", "my eternal ghost" - a ghostly Petersburg of "White Nights" and "Poor people" and possibly "Idiot" by Dostoevsky). Before us the simulative reality of Petersburg, put through the prism of the author's consciousness of Tbilisi, who feels "Petersburg text" of Russian literature as her "own" rather than "foreign". A game of personal and possessive pronouns $I$ - my, we - our looks not antithetical, but establishes a interfacing link between the author and the realities of Petersburg, described in great detail. At the same time, the game of pronouns cognitively refers readers to Vladimir Nabokov's "Gift" ("Dar"), where there is the same technique of a pronouns game to identify the character with the most important person to him a father, lost forever, and is found only in the spiritual space 
of creativity. For I. Kesskiul "Petersburg text" of Russian culture of the individual picture of the world - its most important component.

In addition, another poem by the same author - "Petersburg Symphony" (Kesskiul" 2009, 51). One can clearly see a number of intertextual associations, carrying a critical load in the text: first, the poem has a citation nature and built on signs of modernist culture of the Silver Age of Russian literature, the image that recreates the strokes that create "the effect of recall", which the author wants to achieve. In the second quatrain we can clearly see Voloshin's "intertext in reverse": sonnets, more precisely, a wreath of sonnets "Corona Astralis",which become a pretext to Keskiul's works that can be seen when comparing the epithets - "ice dawn" - in Voloshin's text: "In the dark crimson of non-sunsetting sunsets"; "to climb naked the fire of sonnets" - compare to Voloshin's: "fire clouds, restless fire / Universal storms wandering lights" and his "betraying himself dutifully burn, / You're sad dollars went from the heights of the blind, I dark We were destined by fate / With you on the throne of agony lie". Final "Only empty now Decadent Avenue / Ash obscures the eye. Rastrelli's columns. / About the wrong mouth modern Orpheus / Repeat again that we have not finished singing!" is connotatively relates to Voloshin's "We are fugitives, and behind our Troy, / And we sail a scarlet glow". Before us is a virtual tour of modern Tbilisi of the author "along the trails of scrolls" - it is a projection of poetic fate of the early twentieth century to the present, the discovery of typological their relationship with external difference of historical realities scrapping the old culture and the existence on its ruins.

And to complete the picture the poem by Dmitry Loskutov, a representative of the youth left wing of the literary Tbilisi. In the poem "Oh, Russia, Russia, disperse well...” (2008 Loskutov,
37) we can trace the association with the works of Russian emigre poets of the twentieth century, the motives of G. Ivanov ("Russian happiness. Russian light, / and maybe Russia does not exist ...”), Vladimir Nabokov ("Leave me alone, I beg you ...") and many others. At the same time the poem reveals a distinctive feature of D. Loskutov as a poet - a pronounced civic enthusiasm, which is not so common today in poetry, and not only in the Russian-language poetry of Tbilisi.

Thus, the concept of Russia in the Russianspeaking literary poetic texts of Tbilisi finds the following content: a distant historical homeland, to which a straying child cannot go back; a space of cultural memory; symbol of the great Russian culture, which is becoming a chronotope of Petersburg of the $19^{\text {th }}$ century.

One of the central concepts of literary Russian language picture of the world of Georgia poetry is the concept of Tbilisi, which functions in the texts of the of the chronotope of the modern era. I must say that the city really is a symbol of the changes that have occurred in Georgia over the past 20 years, and the chronicle of these changes is embodied in the texts of Russian poets.

The center of the poetic world holds the poet Vladimir Sarishvili, who began his literary career back in the mid-1980s, writing about the city and the lyrical character - citizen. These two are inextricably intertwined lyrics centers and serve as markers of the author's space and time. The city is represented not simply by a geographical area, but by living crossroads of times, mentalities and cultures. In his poems V. Sarishvili appears to be a poet, whose creative era, alternately succeed each other in the eyes of the lyrical character - a member of the city life, find expression and literary embodiment.

In this sense, the poem of V. Sarishvili "Warlord and Butterflies" is significant (Sarishvili, 2011, 78). Written in easy language, comic in its tone poem, built on the antithesis of 
"the era of Pompey - a couple of thousand years later". The era of Pompey left signs on the earth of Georgia not only in the form of a road, which today is in the city Tbilisi, but also in the form of remnants of Pompey's soldiers, who built a bridge across the river Mtkvari (Kura), which can be viewed at the entrance to Mtskheta the ancient capital of Georgia, and now a small satellite city of Tbilisi. An antithesis of the poem serves as a bridge of time. Comparison of the ancient Roman "commander" of Pompey, the great character of the story, and "Volodia philologist", "little man", an ordinary inhabitant of Tbilisi is extremely significant: in this antithesis the author - an omniscient figure in the text - builds its bridge through time. Hence the situation as described in detail at the bivouac ("Pompey himself in the cloak wide, sitting at rest at night, listening to the greasy anecdote"), the author's knowledge of the beloved Pompey, whom he had left, a future fight with Caesar and the victory of the latter over the other two triumvirs in the battle for power over Rome. The greatness of the past, marked figures Pompey and Caesar, highlights the carnival character of modern writers of reality ("Confetti, garland, beads entwined in a dance around").

The theme of the city is present in the works of a young poet Dmitry Moniava. It is significant in this regard the poem "Grabiura" (Engraving) (Moniava 1998, 12). It is very difficult for its literary character and fullness, Moniava`s poem has several layers: the outer - the description of an ancient engraving; the second - a description of Tbilisi's most hazy of his times - of 19931995. Reading the text through the prism of the second plan allows you to see hidden meanings. Symbolically handed the then realities of city life: no electricity for weeks, became an attribute of not romantic, but necessity candles, kerosene lamps ("extinguished candle", "and only < ..> torches"); broken roads ("Only the abyss"); general chaos of life ("and smallpox, and plague") - in short, new Middle Ages. Today, everyday aspects of life have changed, but the memory of that time remained. It would not be a mistake to regard the text as an attempt to capture Moniava's certain stage of the new mythology of the city, which was formed at the turn of the $21^{\text {st }}$ century in the minds of the citizens, who were exhausted with permanent inconveniences. We would like to note that for many of the authors Tbilisi is a city-myth, which was embodied in the mythology of the old, outgoing Tbilisi (P.Urushadze "city" (Urushadze 2011.31).

Thus, the concept of Tbilisi among Russian poets in Georgia is filled with such ingredients as antiquity, a crossroads of cultures, a historic center, at the same time the eternal city, where new generations compose new myths.

\section{Conclusion}

It is obvious that the Russian-language poetry of Georgia has a long history, the formation of cultural discourse, developing in Georgia has a certain conceptual sphere, were concepts Russia and Tbilisi are dominant, along with other components. They form a particular axis in the space-time coordinates, the center of which is the author's identity. On this basis, it is possible to suggest that the place of cultural identity can be determined in the context of Russian literature, more precisely, within its "Caucasus text" and part of the cultural discourse of modern Georgia. Regardless of this, the perception of the creative product of Russian-speaking poetry of Georgia should be studied as a phenomenon in which a particular worldview of modern man found its literary expression. These peculiarities are the following:

- social trauma and sense of epistemological uncertainty;

- debunking of simulacrum of the past;

- appeal to the metaphysical reality; 
- crisis meta-stories in the author's consciousness;

- carnival character of modern author's reality;
- play with the characters of a bygone culture of modernity (Petersburg text and its interpretation in Russian literature of Georgia).

A reference book, published by S.I. Chuprinin is devoted to the literature in the Russian language as a part of the contemporary literary process (Chuprinin S.I. Foreign contries: Russian Literature Today: [dictionary]. - M.: Vremia, 2008.782p.). In particular it contains a number of names of the representatives of literary circles of Tbilisi.

In the given period the city had a name Tiflis.

3 It is, for example, about the processes of creativity in Russian observed in present-day Ukraine, Belarus, Estonia, Armenia, etc.

4 The term concept is seen in various areas of knowledge. Studying the concept within linguistic concept studies, researchers define it as "a unit of the collective knowledge / awareness, having a linguistic expression and marked with ethnic and cultural characteristics" (Vorkachev 2002). The concept of cultural linguistics is understood as a phenomenon that encompasses comprehension of the world and experience of the individual person and the deep flow of knowledge and ideas about the reality of its specific phenomenon, which was gained by society. Yu.S. Stepanov defines the concept as follows: “... it is like a clot of culture in the human mind; it is a culture that is part of the mental world of man" (Stepanov, 2007, 53). The concept of mentality is usually correlated with the collective representations; most people, a nation, a society a certain period (the mentality of Russian, French, and so on. e.g. the mentality of the Soviet people, the mentality of the peasantry, and so on.). The mentality is often contrasted with the rational thinking activity, ideology as "unreflected sphere, spontaneously evolving thought, not separated from the emotions, habits, techniques of consciousness" (Bolshakov 2004, 251). However, most likely, it includes both components. Mentality, manifesting itself in the sphere of thought, also affects the behavior of the people and, as noted by E. Faryno on "linguistic conceptualization" (Faryno, 2000, 234).

\section{References}

1. Bolshakova A. (2004) Mentalitet. Zapadnoe literaturovedenie 20 v. [Mentality. Western Literature of 20th century. Western literary criticism of the 20th century]: Encyclopedia. INION.

2. Vorkachev S.G. (2002) Metodologicheskie osnovaniia lingvokontseptologii. Teoreticheskaia i prikladnaia lingvistika. Vyp. 3: Aspekty metakommunikativnoi deiatel'nosti [Methodological Bases of Linguistic Studies of Concepts. Theoretical and Applied Linguistics. Vol. 3: Aspects of metacommunicative activities]. Voronezh pp. 79-95. URL:http:// kubstu.ru/docs/lingvoconcept/umbrella. htm.

3. Keskiull I. (2009) Stikhi-IA: Sbornik izbrannykh stikhotvorenii.[Lyrics AZ: selected poems]. Tbilisi: Universal. 112p.

4. Loskutov D. (2008) Stikhotvoreniia [Poems]. Tbilisi. 86p.

5. Megrelishvili T.G. (2012) Modeli samoidentifikatsii i samorefleksii v proze predstavitelei sovremennoi russkoiazychnoi literatury Gruzii - “Vernut'sia v Rossiiu stikhami i prozoi...” Literatura russkogo zarubezh'ia [Models of self-identity and self-reflection in prose, representatives of contemporary Russian-language literature in Georgia - "Back to Russian poetry and prose ..." Russian Literature Abroad] Powrócić doRosjiwierszamiiprozą. Literatura rosyjskiejemidracji-Akademia Pomorska w Słupsku, Słupsk. pp. 366-375.

6. Megrelishvili T.G. (2012) Russkoiazychnaia poeziia-raznovidnost' kul'turnogo repertuara v sovremennoi Gruzii. Rusistika: iazyk, kul'tura, perevod. Sb. nauch. trudov. Sofiiskii gosudarstvennyi universitet im. Klimenta Okhridskogo. Sofia: Istok-Zapad [The Russian-language poetry - a kind of cultural repertoire in modern Georgia. Russian philology: language, culture, translation. Coll. scientific. works. Sophia State University named after Kliment Ohridski. Sofia: East-West]. Pp 566-576.

7. Megrelishvili T.G. (2011) Russkoiazychnaia literatura Gruzii na rubezhe 20-21vv. "Dolg $i$ lyubov",. Sb. nauchnykh trudov. Filologiia. Moskva, "Krug” [Russian literature in Georgia at the 
turn of $20-21^{\text {st }}$ centuries. "It is the duty and love". Coll. scientific papers. Philology. Moscow, "Krug"], pp. 128-137.

8. Megrelishvili T.G. (2011) Russkoiazychnaia poeziia sovremennoi Gruzii: khudozhestvennye tendentsii. "Bolgarskaia rusistika" [The Russian-language poetry of modern Georgia: artistic trends. "Bulgarian Russian Studies”] №3-4, pp. 566-576

9. http://www.actalinguistica.com/arhiv/index.php/bulrus/article/view/422/531

10. Megrelishvili T.G. (2010) Russkoiazychnyi literaturnyi Tbilisi kak iavlenie sovremennogo mezhkul'turnogo diskursa [The Russian-language literary Tbilisi as a phenomenon of contemporary intercultural discourse] Stereotipy v literature i kul'ture. Mezhdunarodnye retseptivnye issledovaniia. Mezhdunarodnoe nauchnoe izdatel'stvo Petera Landa. Frankfurt-na-Maine - Berlin - Bern Briussel'-N'iu-York-Oksford-Vena (Stereotypes in Literatures and Cultures. International Reception Studies. Peter Land internationaler Verlag der Wissenschaften. Frankfurt am Main - Berlin - Bern Bruxelles - New York - Oxford - Wien). 297 p.

11. Megrelishvili T.G. (2008) Russkaia literatura v Gruzii: aktual'nye problemy issledovaniia ( $k$ postanovke voprosa). Russkaia literatura v mirovom kul'turnom i obrazovatel'nom prostranstve. T.I. Ch.1. SPb, Izdatel'skii dom "Mirs" [Russian literature of Georgia: current problems of research (on the problem). Russian literature in the world of cultural and educational space. T.I. Part 1. St. Petersburg publishing house "Mirs"], pp.332-338.

12. Megrelishvili T.G., Modebadze I. I. (2008) Sovremennaia russkoiazychnaia literatura Gruzii. Prikladnaia filologiia: idei, kontseptsii, proekty. Sb. nauch. statei. V 2-kh t. T.II. Rossiia, Tomsk. [Modern Russian-language literature of Georgia. Applied Philology: ideas, concepts and projects. Coll. scientific. articles. The 2 vols. Vol.2. Russia, Tomsk], pp. 74-84.

13. Megrelishvili T.G. (2008) Russkaia literatura Gruzii: aktual'nye problemy issledovaniia (k postanovke voprosa). Russkaia literatura v mirovom kul'turnom i obrazovatel'nom prostranstve. Materialy Mezhdunarodnogo nauchnogo kongressa. Sankt-Peterburg. 15-17 oktiabria. - v 2 t. T.1. Chast' 1. SPb: "Mirs" [Russian literature of Georgia: current problems of research (on the problem). Russian literature in the world of cultural and educational space. Proceedings of the International Scientific Congress. St. Petersburg. October 15-17. - 2 volumes. T.I. Part 1: St. Petersburg: "Mirs"], pp. 332-337.

14. Megrelishvili T.G., Modebadze I.I. (2008) Sovremennaia russkaia literatura Gruzii. Prikladnaia filologiia: idei, kontseptsii, proekty. Sb. nauch. trudov. T.II. Tomsk [Modern Russian Literature of Georgia. Applied Philology: ideas, concepts and projects. Coll. scientific. works. Vol. II. Tomsk], pp. 74-83.

15. Megrelishvili T.G. (2008) Russkoiazychnyi literaturnyi Tbilisi kak iavlenie sovremennogo mezhkul'turnogo diskursa. Sravnitel'noe literaturovedenie: stereotipy v literaturakh i kul'turakh. Sb. materialov III Mezhdunarodnoi nauchnoi konferentsii. Baku. [The Russian-language literary Tbilisi as a phenomenon of contemporary intercultural discourse. Comparative Literature: Stereotypes in literatures and cultures. Coll. Proceedings of the III International Scientific Conference. Baku], pp. 78-83.

16. Modebadze I.I. (2007) Russkoiazychnye vkliucheniia v tekstakh gruzinskoy prozy: istoriia i sovremennost'. Russkii iazyk v stranakh SNG i Baltii. Materialy Mezhdunarodnoi nauchnoi konferentsii. Moskva, 22-23 oktiabria. [Russian-language text inclusions in the Georgian prose: history 
and modernity. Russian language in the CIS and Baltic countries. Proceedings of the International Scientific Conference. Moscow, October 22-23]. Moscow: Nauka, pp. 508-516.

17. Moniava D. (1998) Metamorfozy: Sb. stikhov [Metamorphosis: Coll. poetry]. Tbilisi: Merani, $60 \mathrm{p}$.

18. Na kholmakh Gruzii [On hills of Georgia] // № 4. 2009. Tbilisi.

19. Sarishvili V. (2011) Stikhotvoreniia [Poems]. Tbilisi: Merano, 80p..

20. Stepanov Yu.S. (2007) Konstanty: Slovar' russkoi kul'tury. (M.,1997). Literaturnyi kontsept, kak i lyuboy drugoi, iavliaetsia mental'nym obrazovaniem, otrazhaia "sovokupnost' predstavlenii, poniatii, myslitel'nykh struktur, sposob vospriiatiia mira...” [Constants: Dictionary of Russian culture. (Moscow, 1997). Literary concept, like any other, is a mental formation, reflecting "a set of ideas, concepts, mental structures, way of perceiving the world ...”] (Gurevich P.S. Psychological Dictionary. Moscow, p. 365).

21. Urushadze P. (2001) ) Stikhotvoreniia [Poems]. Tbilisi, "Mera", 114p.

22. Faryno E. (2000) Mentalitet //Idei v Rossii [Mentality // Ideas in Rossia]. Issue 3. Lodz'.

\section{Взаимоотношение концептов \\ художественной картины мира и дискурса \\ в русскоязычной поэзии Грузии}

Т.Г. Мегрелишвили

Грузинский технический университет Грузия, 0175, Тбилиси, Костава, 77

В статье рассматривается вопрос специфики культурного дискурса в русскоязычной поэзии - явлении современного культурного репертуара Грузии. Анализ проводится на материале изучения двух доминант концептосферы - концептов «Россия» $и$ «Тбилиси».

Ключевые слова: русскоязычная поэзия Грузии, постсоветское пространство.

Научная специальность: 10.00.00 - филологические науки. 